\title{
Coordinated Portfolio \\ Investment Survey, 2002 to 2007
}

\section{SUMMARY}

This article analyses the final results from the Coordinated Portfolio Investment Survey (CPIS) 2007 for the United Kingdom and compares these with the 2002 results. An article on portfolio investment holdings by country of residency was last published by the Office for National Statistics three years ago at www.statistics.gov.uk/cci/article. asp?id=1303. This article updates events since that time, focusing on proportionate movements in the estimates between 2002 and 2007 across geographical regions.

\section{Background}

$D$ ortfolio investment is a title to ownership in equity and debt securities issued by a foreignregistered company or a foreign government in order to generate funds. It differs from direct investment in that it does not enable the investor to influence the operations of the company or institution in which they are investing and represents less than ten per cent of equity capital of the enterprise. The nature of portfolio investment is, therefore, less strategic and more liquid than direct investment.

The Coordinated Portfolio Investment Survey (CPIS) is conducted on an annual basis in response to global asymmetries in reported balance of payments data, especially those in portfolio investment flows. The survey aims to provide a comprehensive and harmonised picture of cross-border investments and is overseen by the International Monetary Fund (IMF). The UK's contribution to the CPIS 2007 is recorded in a geographical split of the portfolio investment assets issued by the rest of the world and held by UK residents.

This article analyses the final results for the UK arising from the CPIS 2007 and compares these with the results of 2002. Data was delivered to the IMF in July 2009, and will be published on their website in November 2009. A full country breakdown is available in the Annex which shows the geographical portfolio investment position split by type of security.
Although data are now available from the Office for National Statistics (ONS) publication UK Balance of Payments: the Pink Book 2009, this article is based on data delivered to the IMF and consistent with the ONS Balance of Payments Statistical Bulletin June 2009. Thereafter the initial 2008 data are to be delivered in October 2009 and this will be followed by a final delivery to the IMF in early 2010 when a full sectoral breakdown will be available. It should be noted that coverage of holdings of assets is wider than that presented in this article and further details can be found at the IMF website www.imf. org/external/np/sta/pi/datarsl.htm.

\section{Introduction}

An article on portfolio investment holdings by country of residency was last published by ONS three years ago at www. statistics.gov.uk/cci/article.asp?id=1303. This article aims to bring events since that time up to date, broadening the analysis through an examination of geographic regions rather than countries. This article also describes changes in the distribution of portfolio investment abroad by region since the 2002 CPIS.

\section{Overview}

The financial account and international investment position are primarily made up of three categories; direct investment, portfolio investment and other investment. Examining of each of these forms of investment in terms of net transactions in the UK Financial Accounts emphasises the 
importance of UK portfolio investment to the UK economy in 2007. Net UK portfolio investment at $£ 111.3$ billion was greater than the combined values of direct (admittedly estimates are distorted by the high level of disposals in this period) and other investment. An examination of the international investment position (the stock of assets and liabilities) between 2002 and 2007 revealed that UK direct investment abroad grew by 43.4 per cent to $£ 913.9$ billion while other investment abroad (which mainly comprises the growth of short-term loans, currency and deposits) grew by 142.7 per cent to

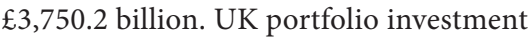
abroad was considerable, rising by 100.7 per cent to $£ 1,693.8$ billion.

Portfolio investment in the UK was $£ 1,917$.6 billion in 2007 , having grown by 107.2 per cent since 2002 .

UK portfolio investment is held in the form of equities, short-term debt securities and long-term debt securities. Holdings of non-resident issued securities in the form of equities were $£ 753.1$ billion, while the remainder, $£ 940.8$ billion, was split between long-term and short-term debt securities. Overwhelmingly, debt securities were held in the form of long-term debt (defined as over one year maturity at time of issue), at $£ 867.5$ billion. The remainder, $£ 73.3$ billion, was mainly held in the form of certificates of deposit or commercial paper, with a maturity of less than one year and is referred to throughout the rest of this article as shortterm debt securities.

Since 2002, the growth of equities at 146.2 per cent outpaced the growth of longterm debt securities at 77.2 per cent. In the same period, growth in short-term debt securities, at 51.1 per cent, was much slower. The remainder of the article will look at each of these three types of security from a broad regional perspective, and will analyse how various proportions have changed in the intervening five years. The article will conclude with an afterword about the phenomenon of offshore financial centres and emerging economies.

\section{Regional distribution}

Figure 1 shows the distribution among broad geographic regions in accordance with the balance of payments vademecum (the reference document published by the Statistical Commission of the European Commission in December 2007). Figure 1 illustrates that the proportion held in Europe of overall UK portfolio investment was the largest regional share at 42.7 per cent followed by America (North, Central and
South) at 32.7 per cent. The region identified within the figure's legend as 'Rest' includes countries not shown elsewhere and various international organisations.

\section{Equities}

Since 2002, the growth of equities at 146.2 per cent was approximately double that of debt securities. This growth is a reflection of the world equity markets which performed strongly over the period 2002-2007, as a generally benign world economy underpinned a strong period of growth.

Figure 2 shows some key stock market indices from within the broad regions covered by UK portfolio investment. The level of the Shanghai composite index within China had increased by over 180 per cent, with rapid growth towards the end of the period, the Hang Seng in Hong Kong had increased by more than 135 per cent, whilst the Dax in Germany and the AORD in Australia had grown by around 100 per cent. Growth in the Egyptian stock exchange, though only established in 2004 was remarkable (around 270 per cent) and hints at some of the strength in Northern African countries' financial markets. At the same time, growth in the US, Japan, France and the EuroStoxx indicator had been between 45 to 60 per cent. In the UK, the FTSE-100 had grown by around 45 per cent.

Overall, the survey for 2007 showed that holdings of equities was highest in Europe where its share fell from 48.2 per cent in 2002 to 39.9 per cent in 2007 (Figure 3). The share for America fell from 31.8 per cent in 2002 to 27.6 per cent in 2007. Asia increased its share from 5.9 per cent to 25.6 per cent. The accumulation of equities between 2002 and 2007 has primarily been located in three regions: Europe, America and Asia and they represented 93.1 per cent of all holdings abroad. However, these holdings had risen 7.2 per cent on the proportion these regions held in 2002.

Within Europe in 2007, Germany, Ireland and France attracted 6.3 per cent, 5.3 per cent and 4.8 per cent respectively of all UK equity investment abroad while Switzerland and the Netherlands also had significant investment. In the Americas, the United States had the highest proportion of world equity investment at 24.0 per cent. In Asia, the three main destinations for equity investment were Japan at 9.7 per cent, Hong Kong at 2.7 per cent and the People's Republic of China at 2.5 per cent. In the region of Oceania, which had a world share of 2.6 per cent,

Figure 1

Overall overseas portfolio investment, 2007

Percentage of total

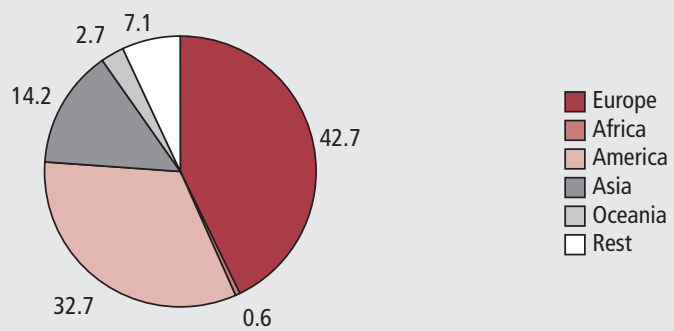

Source: CPIS

Figure 2

Growth in stock market indices, 2002-2007

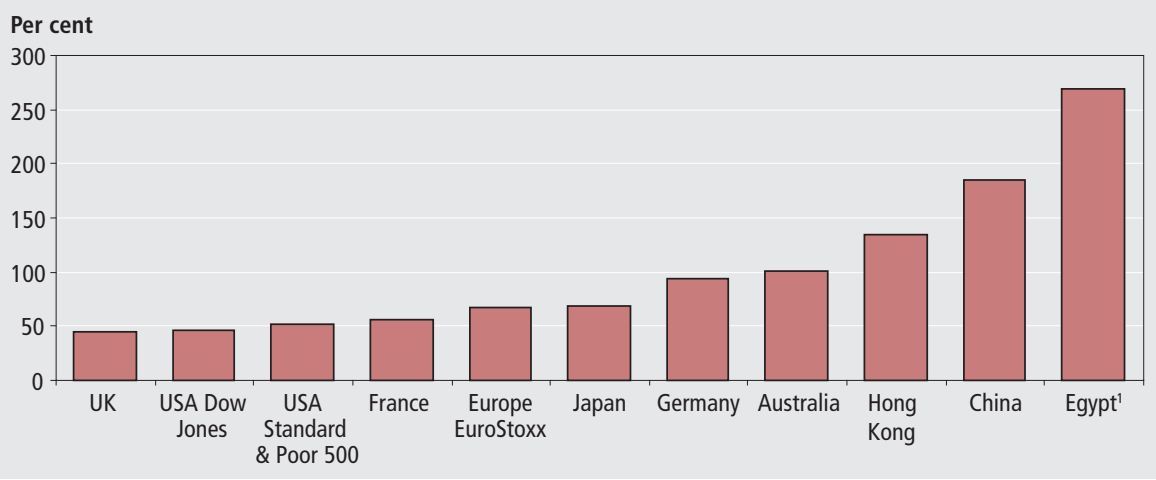

1 Growth from 2004 when index began. 


\section{Figure 3 \\ Portfolio investment - equities}

Per cent

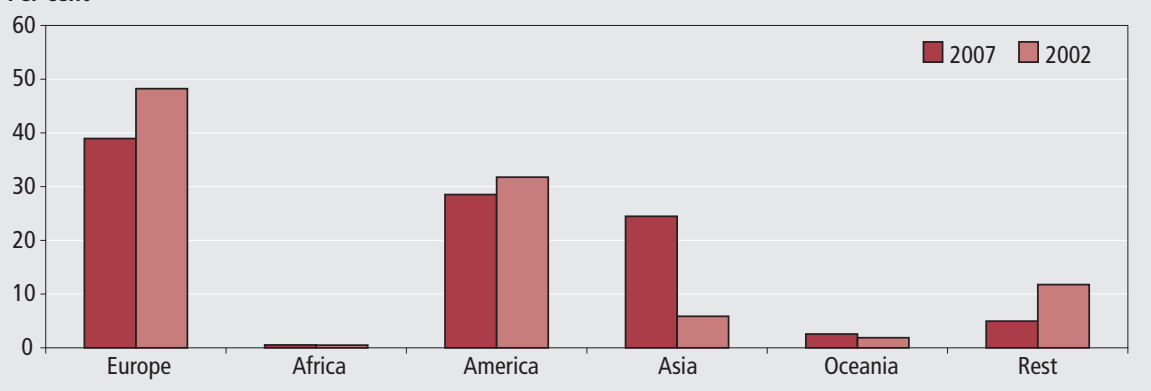

Source: CPIS

\section{Figure 4 \\ Portfolio investment - long-term debt securities}

Per cent

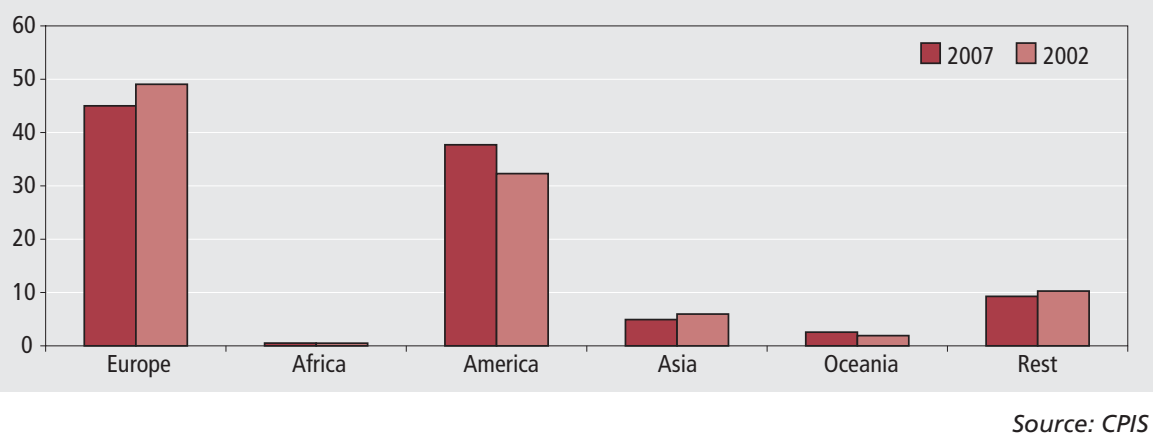

Figure 5

\section{Portfolio investment - short-term debt securities}

\section{Per cent}

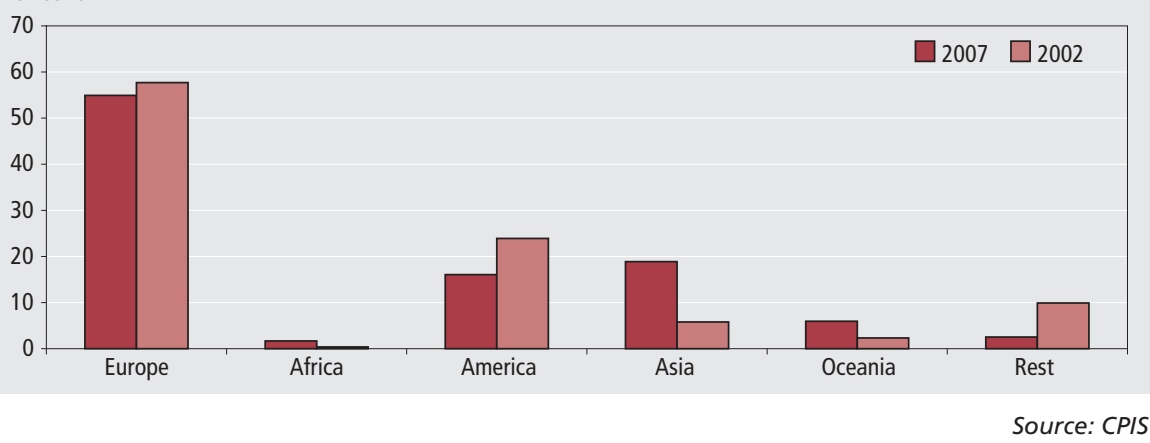

Australia was the primary destination for equity investment at 2.5 per cent.

The strong growth in UK portfolio investment abroad illustrated by the data coincided with growth in company valuations, perhaps reflecting increasing confidence and opportunities available from more liberalised market economies. The rapid growth in some of the developing countries beyond that seen in some of the established markets, coupled with a potential lack of internal finance, was integral to the expansion of UK portfolio holdings in these areas.

\section{Long-term debt securities}

As shown in Figure 4 the largest target area for investment in long-term debt securities was Europe at 45.0 per cent which was a decrease of 4.1 per cent since 2002. Within Europe, the three largest recipients of UK funding were Ireland at 6.4 per cent, Netherlands at 6.3 per cent and Germany at 5.3 per cent. By contrast, the proportion of investment in America increased from 32.3 per cent in 2002 to 37.7 per cent in 2007 . The three main sources for issuance of long-term debt securities within America were the United States at 27.7 per cent, the Cayman Islands at 7.3 per cent and Canada at 1.3 per cent. The world share of holdings in Asia fell, from 6.0 per cent in 2002 to 4.9 per cent in 2007. Japan held 2.1 per cent of market share while the Republic of Korea held 0.6 per cent and India held 0.4 per cent.

\section{Short-term debt securities}

Short-term debt securities located within Europe fell from 57.7 per cent in 2002 to 54.9 per cent in 2007 (Figure 5). In Europe there were three main recipients of UK funds; France, at 12.1 per cent, had the largest proportion followed by Ireland at 10.5 per cent and Germany at 8.6 per cent. In America, the United States held the largest proportion at 14.2 per cent. Within the Americas, holdings in Canada, Cayman Islands and Chile were estimated at 0.6 per cent, 0.4 per cent and 0.3 per cent respectively.

\section{Offshore financial centres and emerging economies}

The issuance of capital to foreign-based investors is an important source of finance for the private sector in economies with a limited internal credit market and a restricted ability to generate private investment funds from households. Equally, this has operated as an important policy instrument for government within developing economies where a greater yield than government bonds in developed economies was achieved and, as such, potentially induces foreign investment.

Inspection of the survey results of UK resident holdings of issues by offshore financial centres between 2002 and 2007 indicated more rapid growth in equities and long-term debt securities, but it must be emphasised this originated from a lower base than historically traditional areas of investment for UK residents, such as America (particularly the United States), Asia (primarily Japan) and Europe (in general, the EU12 countries). Nonetheless, growth was extremely strong in the Russian Federation, the People's Republic of China and the Near and Middle Eastern countries and there was significant growth of holdings within the continent of Africa.

Given the lower starting level and relative immaturity of financial market liberalisation in some developing economies and the likely expansion of these sectors in the future, it is possible that the shifting trend in growth away from developed economies will continue. The key driver in these developments might be explained by patterns in returns in developing economies, and by the faster rate of GDP growth.

Figure 6 presents annual GDP estimates from the Organisation of Economic Cooperation and Development (OECD) which have been converted to constant price purchasing power parity adjusted dollars and indicates that average growth in the US over this period was 2.6 per cent. This is greater 


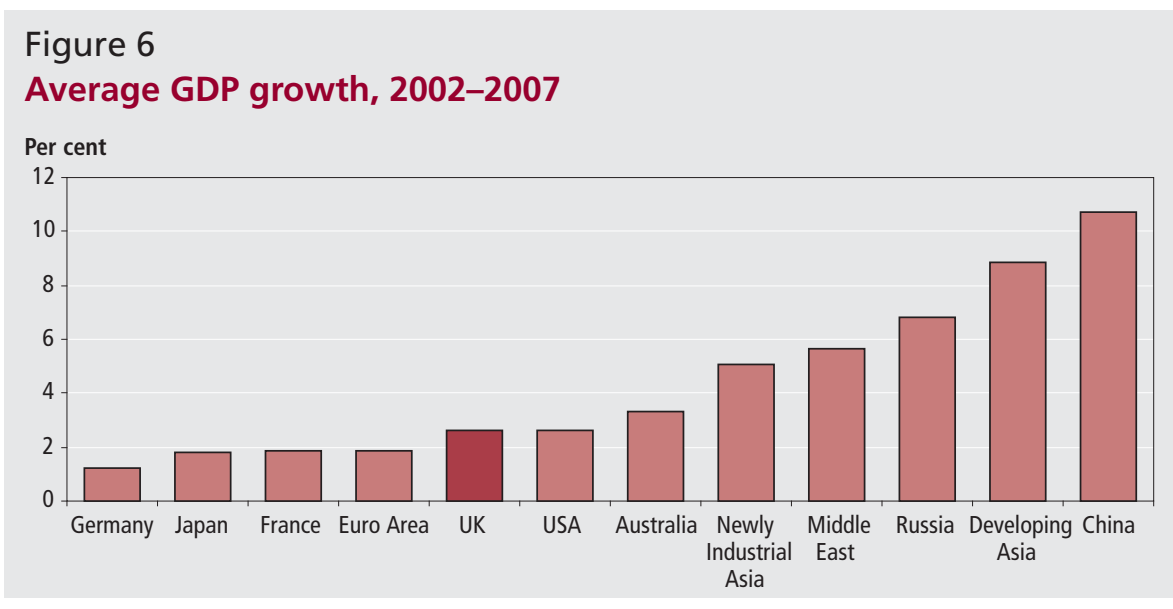

Note:

1 Data for OECD countries taken from OECD statistics database in constant price PPP terms, data for the broad regions and China taken from the IMF in constant price non-PPP terms.

than the euro area average of 1.9 per cent. The rates for France and Germany (two of the bigger shares of portfolio investment) were below the euro area average (1.8 per cent and 1.2 per cent respectively). Growth in Australia had been 3.3 per cent, outperforming the UK which had averaged 2.6 per cent growth. The OECD figure for Russia showed an average growth of 6.8 per cent, higher than most other European countries following a previous period of severe retrenchment.

In Asia, the OECD reports that in Japan, growth averaged 1.8 per cent, compared to 5.1 per cent in the newly industrialised economies of Hong Kong, South Korea, Singapore and Taiwan. Growth in China and other developing Asian economies was not available on the OECD statistics database but IMF data indicates an average annual growth of 10.7 per cent over the period (at constant prices but not purchasing power parity adjusted). The IMF also provides data for the Middle East and developing Asian economies, two of the areas of strong growth in portfolio investment. Average growth in the Middle East was 5.7 per cent and in developing Asia, there was an average increase of 8.9 per cent.

\section{Average GDP growth, 2002-2007}

Real growth (Figure 6) in the developing economies in Asia and in Russia exceeded that in the rest of the world and growth in the Middle East and newly industrialised
Asia has exceeded that in the developed world. So the prospects of relatively stronger growth in these areas over this period would have been relatively appealing for foreign investors. The data for nonOECD countries is in non-purchasing power parity adjusted terms; this is likely to make some difference to the figures but is unlikely to be enough to change the relative positions of the economies over this period.

Considering returns in more detail, it is not simply the case that GDP growth was quicker which drove returns. There was an element of higher returns in these economies due to a higher risk premium associated with them. At this point in time, there was a greater willingness to take on a share of riskier assets offering a higher return and this will have contributed to the diversification in UK portfolio investment as indicated by the data. This is still consistent with an increasing share of investment in the USA as there will always be a need to offset investment considered more risky with a portfolio of assets considered to be safe. UK holdings in US assets have increased in the safer category of assets (debt securities) to a greater extent than the less secure assets (equities) as US Treasury bills are considered to be one of the safest investments available.

Overall the movement in UK portfolio holdings reflects an increase in the importance of high quality US assets and an increased willingness to invest in developing countries at the expense of European-based assets. Whether this picture will continue past 2007 will reflect investors' expectations about the future prospects of different regions and economies. There is likely to be a diminished supply of funds for foreign portfolio investment if we take into account recent output and labour market developments alone. Moreover, in respect of restrictions operating at present in money markets, it seems possible that growth in portfolio investment may weaken significantly by the time of the next data release.

It is possible a 'flight to quality' in the wake of recent economic issues may occur, but where the market might predict 'quality' investments is not something that can be determined at present. Given that the current crisis was lead by US financial institutions and it is the developing economies which appear to be growing, it is possible that there may be a movement away from US assets by UK investors. Observing more recent developments in equity markets shows there was a marked deterioration worldwide (with falls of between 5 per cent in Egypt and 40 per cent in China over 2008 as a whole); indeed, no single market escaped the impact of the shock to the global financial system.

\section{Conclusion}

The results suggest UK portfolio investment abroad has remained concentrated around three regions - Europe, America and Asia. Growth in these regions has to an extent disguised rapid change in certain offshore financial centres and newly emergent economies. It should be remembered that the faster pace of growth in these has arisen from much smaller bases than traditional regions and countries. It is therefore likely that portfolio investment will continue to be attracted to traditional locations and countries such as western Europe and the United States. The relative movements in GDP and confidence going forward will continue to influence the direction of flows of money, as the world economy still faces unprecedented uncertainty in financial markets.

\section{CONTACT}

elmr@ons.gsi.gov.uk 


\section{ANNEX}

The table below shows the holdings of UK portfolio investment by financial instrument for the period 2007 for individual countries. Further details of portfolio coverage can be found on the IMF website: www.imf.org/external/sta/pi/datarsl.htm.

Table A1

Holdings of UK portfolio investment by financial instrument for individual countries, 2007

f million

\begin{tabular}{|c|c|c|c|c|c|}
\hline Country of non-resident issuer & Equities & Total debt & $\begin{array}{r}\text { Long-term debt } \\
\text { securities }\end{array}$ & $\begin{array}{r}\text { Short-term debt } \\
\text { securities }\end{array}$ & Total \\
\hline Afghanistan, Islamic State of & 0 & 0 & 0 & 0 & 0 \\
\hline Albania & 3 & 11 & 11 & 0 & 14 \\
\hline Algeria & 1 & -1 & -1 & 0 & -1 \\
\hline American Samoa & 0 & 0 & 0 & 0 & 0 \\
\hline Andorra & 0 & -18 & -18 & 0 & -18 \\
\hline Angola & 0 & 84 & 84 & 0 & 84 \\
\hline Anguilla & 22 & 309 & 299 & 10 & 331 \\
\hline Antigua and Barbuda & 0 & 0 & 0 & 0 & 0 \\
\hline Argentina & 561 & 2,052 & 2,097 & -45 & 2,612 \\
\hline Armenia & 0 & 0 & 0 & 0 & 0 \\
\hline Aruba & 0 & 78 & 78 & 0 & 78 \\
\hline Australia & 18,939 & 24,215 & 20,883 & 3,332 & 43,155 \\
\hline Austria & 2,707 & 6,165 & 5,506 & 658 & 8,872 \\
\hline Azerbaijan & 0 & 69 & 13 & 56 & 69 \\
\hline Bahamas, The & 89 & 108 & 108 & 0 & 197 \\
\hline Bahrain & 31 & 411 & 347 & 63 & 442 \\
\hline Bangladesh & 17 & 18 & 0 & 18 & 35 \\
\hline Barbados & 8 & 46 & 46 & 0 & 54 \\
\hline Belarus & 0 & 11 & 10 & 1 & 11 \\
\hline Belgium & 3,963 & 6,069 & 5,737 & 332 & 10,032 \\
\hline Belize & 0 & 0 & 0 & 0 & 0 \\
\hline Benin & 0 & 0 & 0 & 0 & 0 \\
\hline Bermuda & 5,800 & 1,334 & 1,326 & 8 & 7,134 \\
\hline Bhutan & 0 & 0 & 0 & 0 & 0 \\
\hline Bolivia & 5 & 0 & 0 & 0 & 5 \\
\hline Bosnia and Herzegovina & 0 & 36 & 36 & 0 & 36 \\
\hline Botswana & 0 & 0 & 0 & 0 & 0 \\
\hline Brazil & 9,395 & 4,560 & 4,434 & 126 & 13,955 \\
\hline British Indian Ocean Territory & 0 & 0 & 0 & 0 & 0 \\
\hline Brunei Darussalam & -4 & 0 & 0 & 0 & -4 \\
\hline Bulgaria & 41 & 59 & 43 & 16 & 100 \\
\hline Burkina Faso & 0 & 0 & 0 & 0 & 0 \\
\hline Burundi & 0 & 0 & 0 & 0 & 0 \\
\hline Cambodia & 0 & 0 & 0 & 0 & 0 \\
\hline Cameroon & 0 & 3 & 3 & 0 & 3 \\
\hline Canada & 62 & 12,050 & 11,588 & 462 & 12,112 \\
\hline Cape Verde & 0 & 0 & 0 & 0 & 0 \\
\hline Cayman Islands & 17,051 & 63,306 & 62,994 & 312 & 80,358 \\
\hline Central African Republic & 0 & 0 & 0 & 0 & 0 \\
\hline Chad & 0 & 0 & 0 & 0 & 0 \\
\hline Chile & 427 & 470 & 253 & 217 & 897 \\
\hline China, P.R. & 18,746 & 637 & 557 & 80 & 19,382 \\
\hline Christmas Island & 0 & 0 & 0 & 0 & 0 \\
\hline Cocos (Keeling) Islands & 0 & 0 & 0 & 0 & 0 \\
\hline Colombia & 72 & 337 & 336 & 1 & 409 \\
\hline Comoros & 0 & 0 & 0 & 0 & 0 \\
\hline Congo, Dem. Rep. of & 0 & 0 & 0 & 0 & 0 \\
\hline Congo, Rep. of & 0 & 8 & 8 & 0 & 8 \\
\hline Cook Islands & 0 & 0 & 0 & 0 & 0 \\
\hline Costa Rica & 0 & 85 & 84 & 1 & 85 \\
\hline Côte d'Ivoire & 1 & 75 & 75 & 0 & 76 \\
\hline Croatia & 18 & 344 & 300 & 44 & 362 \\
\hline Cuba & 1 & 53 & 50 & 3 & 53 \\
\hline Cyprus & 394 & 346 & 339 & 7 & 740 \\
\hline Czech Republic & 477 & 588 & 587 & 1 & 1,065 \\
\hline Denmark & 3,430 & 7,430 & 7,373 & 57 & 10,859 \\
\hline Djibouti & 0 & 0 & 0 & 0 & 0 \\
\hline Dominica & 0 & 0 & 0 & 0 & 0 \\
\hline
\end{tabular}


Table A1 continued

\begin{tabular}{|c|c|c|c|c|c|}
\hline Country of non-resident issuer & Equities & Total debt & $\begin{array}{r}\text { Long-term debt } \\
\text { securities }\end{array}$ & $\begin{array}{r}\text { Short-term debt } \\
\text { securities }\end{array}$ & Total \\
\hline Dominican Republic & 0 & 449 & 429 & 19 & 449 \\
\hline Ecuador & 0 & 70 & 65 & 5 & 70 \\
\hline Egypt & 508 & 1,554 & 841 & 712 & 2,062 \\
\hline El Salvador & 0 & 12 & 12 & 0 & 11 \\
\hline Equatorial Guinea & 0 & 0 & 0 & 0 & 0 \\
\hline Eritrea & 0 & 0 & 0 & 0 & 0 \\
\hline Estonia & 9 & 9 & 9 & 0 & 18 \\
\hline Ethiopia & 1 & 0 & 0 & 0 & 1 \\
\hline Falkland Islands (Malvinas) & 0 & 0 & 0 & 0 & 0 \\
\hline Faroe Islands & 0 & 0 & 0 & 0 & 0 \\
\hline Fiji & 0 & 7 & 7 & 0 & 7 \\
\hline Finland & 10,885 & 3,456 & 3,020 & 436 & 14,341 \\
\hline France & 36,482 & 51,371 & 42,528 & 8,843 & 87,853 \\
\hline French Guiana & 0 & 0 & 0 & 0 & 0 \\
\hline French Polynesia & 0 & 0 & 0 & 0 & 0 \\
\hline French Southern Territories & 0 & 0 & 0 & 0 & 0 \\
\hline Gabon & 0 & 9 & 9 & 0 & 10 \\
\hline Gambia, The & 0 & 4 & 0 & 4 & 4 \\
\hline Georgia & 0 & 19 & 19 & 0 & 19 \\
\hline Germany & 47,598 & 52,014 & 45,709 & 6,306 & 99,613 \\
\hline Ghana & $\begin{array}{lllll}-4 & & r & & \end{array}$ & 193 & 168 & 26 & 189 \\
\hline Gibraltar & 1,180 & -405 & -405 & 0 & 775 \\
\hline Greece & 5,157 & 4,650 & 4,542 & 108 & 9,807 \\
\hline Greenland & 0 & 0 & 0 & 0 & 0 \\
\hline Grenada & 0 & 1 & 1 & 0 & 1 \\
\hline Guadeloupe & -2 & 0 & 0 & 0 & -2 \\
\hline Guam & -2 & 0 & 0 & 0 & -2 \\
\hline Guatemala & 0 & 12 & 12 & 0 & 12 \\
\hline Guernsey & 2,189 & 981 & 972 & 9 & 3,170 \\
\hline Guinea & 0 & 0 & 0 & 0 & 0 \\
\hline Guinea-Bissau & 0 & 0 & 0 & 0 & 0 \\
\hline Guyana & 22 & 14 & 14 & 0 & 36 \\
\hline Haiti & 0 & 0 & 0 & 0 & 0 \\
\hline Honduras & 0 & 2 & 2 & 0 & 2 \\
\hline Hong Kong SAR of China & 20,223 & 1,617 & 1,389 & 228 & 21,840 \\
\hline Hungary & 748 & 1,335 & 1,315 & 20 & 2,083 \\
\hline Iceland & 70 & 3,089 & 3,089 & 0 & 3,159 \\
\hline India & 16,577 & 4,371 & 3,667 & 704 & 20,948 \\
\hline Indonesia & 2,277 & 1,137 & 1,098 & 40 & 3,414 \\
\hline Iran, Islamic Republic of & 0 & 584 & 177 & 407 & 584 \\
\hline Iraq & 0 & 9 & 9 & 0 & 9 \\
\hline Ireland & 40,371 & 63,594 & 55,934 & 7,659 & 103,965 \\
\hline Isle of Man & 985 & 380 & 373 & 7 & 1,365 \\
\hline Israel & 1,331 & 809 & 803 & 6 & 2,141 \\
\hline Italy & 14,270 & 42,588 & 38,667 & 3,922 & 56,858 \\
\hline Jamaica & 2 & 125 & 83 & 42 & 127 \\
\hline Japan & 72,960 & 29,164 & 18,549 & 10,615 & 102,124 \\
\hline Jersey & 4,137 & 21,834 & 17,644 & 4,190 & 25,971 \\
\hline Jordan & 10 & 1 & 1 & 0 & 11 \\
\hline Kazakhstan & 133 & 1,221 & 972 & 249 & 1,354 \\
\hline Kenya & 0 & 2 & 0 & 2 & 2 \\
\hline Kiribati & 0 & 0 & 0 & 0 & 0 \\
\hline Korea, Democratic People's Republic of & 1,175 & 35 & 33 & 2 & 1,210 \\
\hline Korea, Republic of & 14,215 & 5,590 & 5,422 & 168 & 19,805 \\
\hline Kuwait & 135 & 551 & 290 & 262 & 687 \\
\hline Kyrgyz Republic & 0 & 0 & 0 & 0 & 0 \\
\hline Lao People's Democratic Republic & 12 & 0 & 0 & 0 & 12 \\
\hline Latvia & 0 & 5 & 1 & 4 & 6 \\
\hline Lebanon & 4 & 126 & 112 & 14 & 129 \\
\hline Lesotho & 0 & 0 & 0 & 0 & 0 \\
\hline Liberia & -16 & 78 & 78 & 0 & 62 \\
\hline Libya & 0 & 0 & 0 & 0 & 0 \\
\hline Liechtenstein & 7 & 106 & 106 & 0 & 113 \\
\hline
\end{tabular}


Table A1 continued

\begin{tabular}{|c|c|c|c|c|c|}
\hline Country of non-resident issuer & Equities & Total debt & $\begin{array}{r}\text { Long-term debt } \\
\text { securities }\end{array}$ & $\begin{array}{r}\text { Short-term debt } \\
\text { securities }\end{array}$ & Total \\
\hline Lithuania & 1 & 37 & 37 & 0 & 39 \\
\hline Luxembourg & 17,147 & 26,206 & 25,918 & 288 & 43,353 \\
\hline Macao SAR of China & 0 & 1 & 0 & 1 & 1 \\
\hline Macedonia, FYR & 0 & 0 & 0 & 0 & 0 \\
\hline Madagascar & 0 & 0 & 0 & 0 & 0 \\
\hline Malawi & 0 & 8 & 8 & 0 & 8 \\
\hline Malaysia & 3,203 & 2,079 & 1,599 & 480 & 5,282 \\
\hline Maldives & 0 & 1 & 0 & 1 & 1 \\
\hline Mali & 1 & 3 & 3 & 0 & 4 \\
\hline Malta & 34 & 0 & 0 & 0 & 34 \\
\hline Marshall Islands & 2 & 6 & 6 & 0 & 8 \\
\hline Martinique & 0 & 0 & 0 & 0 & 0 \\
\hline Mauritania & 0 & 2 & 2 & 0 & 2 \\
\hline Mauritius & 348 & 118 & 114 & 4 & 466 \\
\hline Mayotte & 0 & 0 & 0 & 0 & 0 \\
\hline Mexico & 3,027 & 2,343 & 2,214 & 129 & 5,370 \\
\hline Micronesia, Federated States of & 0 & 0 & 0 & 0 & 0 \\
\hline Moldova & 0 & 0 & 0 & 0 & 0 \\
\hline Monaco & 0 & 0 & 0 & 0 & 0 \\
\hline Mongolia & 0 & 10 & 10 & 0 & 10 \\
\hline Montenegro, Republic of & 0 & 0 & 0 & 0 & 0 \\
\hline Montserrat & 0 & 0 & 0 & 0 & 0 \\
\hline Morocco & 33 & 61 & 57 & 4 & 94 \\
\hline Mozambique & 0 & 0 & 0 & 0 & 0 \\
\hline Myanmar & 0 & 0 & 0 & 0 & 0 \\
\hline Namibia & 0 & 1 & 1 & 0 & 1 \\
\hline Nauru & 0 & 0 & 0 & 0 & 0 \\
\hline Nepal & 0 & 0 & 0 & 0 & 0 \\
\hline Netherlands & 20,267 & 57,954 & 54,763 & 3,192 & 78,221 \\
\hline Netherlands Antilles & 594 & 745 & 745 & 0 & 1,339 \\
\hline New Caledonia & 0 & 0 & 0 & 0 & 0 \\
\hline New Zealand & 318 & 2,363 & 1,333 & 1,030 & 2,681 \\
\hline Nicaragua & 0 & 0 & 0 & 0 & 0 \\
\hline Niger & 0 & 1 & 1 & 0 & 1 \\
\hline Nigeria & 20 & 1,353 & 916 & 437 & 1,373 \\
\hline Niue & 0 & 0 & 0 & 0 & 0 \\
\hline Norfolk Island & 0 & 0 & 0 & 0 & 0 \\
\hline Norway & 7,391 & 6,778 & 6,317 & 461 & 14,170 \\
\hline Oman & 19 & 27 & 15 & 12 & 46 \\
\hline Pakistan & 265 & 53 & 41 & 12 & 318 \\
\hline Palau & 0 & 0 & 0 & 0 & 0 \\
\hline Panama & 720 & 122 & 109 & 12 & 842 \\
\hline Papua New Guinea & 78 & 0 & 0 & 0 & 78 \\
\hline Paraguay & 0 & 0 & 0 & 0 & 0 \\
\hline Peru & 207 & 221 & 185 & 36 & 428 \\
\hline Philippines & 1,000 & 647 & 638 & 9 & 1,647 \\
\hline Pitcairn & 0 & 0 & 0 & 0 & 0 \\
\hline Poland & 948 & 2,182 & 2,015 & 167 & 3,130 \\
\hline Portugal & 2,535 & 4,603 & 4,233 & 370 & 7,138 \\
\hline Puerto Rico & 2 & 0 & 0 & 0 & 2 \\
\hline Qatar & 405 & 284 & 231 & 53 & 689 \\
\hline Réunion & 0 & 0 & 0 & 0 & 0 \\
\hline Romania & 109 & 173 & 145 & 28 & 282 \\
\hline Russian Federation & 9,126 & 6,877 & 6,408 & 470 & 16,004 \\
\hline Rwanda & 0 & 0 & 0 & 0 & 0 \\
\hline St. Helena & 0 & 0 & 0 & 0 & 0 \\
\hline St. Kitts and Nevis & 0 & 0 & 0 & 0 & 0 \\
\hline St. Lucia & 0 & 0 & 0 & 0 & 0 \\
\hline St. Pierre and Miquelon & 0 & 0 & 0 & 0 & 0 \\
\hline St. Vincent and the Grenadines & 0 & 0 & 0 & 0 & 0 \\
\hline Samoa & 0 & 0 & 0 & 0 & 0 \\
\hline San Marino & 0 & 5 & 5 & 0 & 5 \\
\hline São Tomé and Príncipe & 0 & 3 & 3 & 0 & 3 \\
\hline Saudi Arabia & 211 & 344 & 210 & 134 & 555 \\
\hline
\end{tabular}


Table A1 continued

\begin{tabular}{|c|c|c|c|c|c|}
\hline Country of non-resident issuer & Equities & Total debt & $\begin{array}{r}\text { Long-term debt } \\
\text { securities }\end{array}$ & $\begin{array}{r}\text { Short-term debt } \\
\text { securities }\end{array}$ & Total \\
\hline Senegal & 0 & 6 & 0 & 6 & 6 \\
\hline Serbia, Republic of & 0 & 8 & 8 & 0 & 8 \\
\hline Seychelles & 0 & 15 & 15 & 0 & 15 \\
\hline Sierra Leone & 0 & 0 & 0 & 0 & 0 \\
\hline Singapore & 8,640 & 1,831 & 1,806 & 25 & 10,471 \\
\hline Slovak Republic & 0 & 551 & 545 & 7 & 551 \\
\hline Slovenia & 41 & 190 & 168 & 22 & 231 \\
\hline Solomon Islands & 0 & 0 & 0 & 0 & 0 \\
\hline Somalia & 0 & 0 & 0 & 0 & 0 \\
\hline South Africa & 3,136 & 1,961 & 1,940 & 21 & 5,097 \\
\hline Spain & 14,443 & 35,574 & 35,217 & 357 & 50,017 \\
\hline Sri Lanka & 98 & 29 & 19 & 10 & 127 \\
\hline Sudan & 0 & 4 & 4 & 0 & 4 \\
\hline Suriname & 0 & 0 & 0 & 0 & 0 \\
\hline Swaziland & 0 & 0 & 0 & 0 & 0 \\
\hline Sweden & 9,057 & 9,470 & 8,448 & 1,022 & 18,527 \\
\hline Switzerland & 34,269 & 7,126 & 6,680 & 446 & 41,395 \\
\hline Syrian Arab Republic & 0 & 0 & 0 & 0 & 0 \\
\hline Taiwan Province of China & 11,170 & 550 & 527 & 23 & 11,720 \\
\hline Tajikistan & 0 & 0 & 0 & 0 & 0 \\
\hline Tanzania & 0 & 5 & 4 & 1 & 5 \\
\hline Thailand & 3,082 & 210 & 198 & 12 & 3,291 \\
\hline Timor-Leste & 0 & 0 & 0 & 0 & 0 \\
\hline Togo & 0 & 0 & 0 & 0 & 0 \\
\hline Tokelau & 0 & 0 & 0 & 0 & 0 \\
\hline Tonga & -10 & 0 & 0 & 0 & -10 \\
\hline Trinidad and Tobago & 0 & 56 & 56 & 0 & 56 \\
\hline Tunisia & 1 & 107 & 103 & 4 & 108 \\
\hline Turkey & 2,751 & 5,191 & 4,786 & 405 & 7,942 \\
\hline Turkmenistan & 0 & 0 & 0 & 0 & 0 \\
\hline Turks and Caicos Islands & 0 & 0 & 0 & 0 & 0 \\
\hline Tuvalu & 0 & 0 & 0 & 0 & 0 \\
\hline Uganda & 0 & 32 & 30 & 2 & 32 \\
\hline Ukraine & 45 & 1,647 & 1,315 & 332 & 1,692 \\
\hline United Arab Emirates & 1,174 & 2,100 & 1,909 & 191 & 3,274 \\
\hline United Kingdom & 0 & 0 & 0 & 0 & 0 \\
\hline United States & 180,414 & 250,670 & 240,246 & 10,424 & 431,083 \\
\hline United States Minor Outlying Islands & 0 & 0 & 0 & 0 & 0 \\
\hline Uruguay & 5 & 102 & 100 & 2 & 107 \\
\hline Uzbekistan & 0 & 0 & 0 & 0 & 0 \\
\hline Vanuatu & 0 & 0 & 0 & 0 & 0 \\
\hline Vatican City State & 0 & 0 & 0 & 0 & 0 \\
\hline Venezuela, República Bolivariana de & 0 & 453 & 447 & 6 & 454 \\
\hline Vietnam & 795 & 39 & 39 & 0 & 835 \\
\hline Virgin Islands, British & 2,534 & 733 & 733 & 0 & 3,268 \\
\hline Virgin Islands, U.S. & 126 & 8 & 8 & 0 & 133 \\
\hline Wallis and Futuna Islands & 0 & 0 & 0 & 0 & 0 \\
\hline West Bank and Gaza Strip & 0 & 0 & 0 & 0 & 0 \\
\hline Western Sahara & 0 & 0 & 0 & 0 & 0 \\
\hline Yemen, Republic of & 0 & 5 & 5 & 0 & 5 \\
\hline Zambia & 1 & 17 & 17 & 0 & 18 \\
\hline Zimbabwe & 1 & 0 & 0 & 0 & 1 \\
\hline Other countries (confidential data) & 961 & 14,413 & 13,597 & 817 & 15,375 \\
\hline Other countries (unallocated) & 34,983 & 36,051 & 35,963 & 88 & 71,035 \\
\hline International organisations & 1,438 & 31,862 & 30,911 & 950 & 33,300 \\
\hline Total value of investment & 753,075 & 940,751 & 867,474 & 73,277 & $1,693,826$ \\
\hline
\end{tabular}

